\title{
New record of predatory ladybird beetle (Coleoptera, Coccinellidae) feeding on extrafloral nectaries
}

\author{
Lúcia M. Almeida ${ }^{1}$, Geovan H. Corrêa ${ }^{1}$, José A. Giorgi ${ }^{2}$ \& Paschoal C. Grossi ${ }^{1}$ \\ ${ }^{1}$ Laboratório de Sistemática e Bioecologia de Coleoptera (Insecta), Departamento de Zoologia, Universidade Federal do Paraná, Caixa Postal 19020, \\ 81581-980 Curitiba-PR, Brazil. lalmeida@ufpr.br; geovanbiologo@yahoo.com.br; paschoal.grossi@gmail.com \\ ${ }^{2}$ Entomologia, Universidade Federal Rural de Pernambuco, Rua Dom Manoel de Medeiros, s/n, Dois Irmãos, 52171-900 Recife-PE, Brazil. \\ coccinellid@gmail.com
}

\begin{abstract}
New record of predatory ladybird beetle (Coleoptera, Coccinellidae) feeding on extrafloral nectaries. Feeding by Exoplectra miniata (Germar) on extrafloral nectaries of Inga edulis Mart. was observed in Nova Friburgo, Rio de Janeiro, Brazil. This is the first record of this behavior for Exoplectrini.

KEYWORDS. Alimentary resources; Exoplectra miniata; Exoplectrini; Inga edulis; Leguminosae.

RESUMO. Novo registro de um coccinelídeo predador (Coleoptera, Coccinellidae) alimentando-se de nectário extrafloral. A alimentação de Exoplectra miniata (Germar) em nectários extraflorais de Inga edulis Mart. foi observada em Nova Friburgo, Rio de Janeiro, Brasil. Este é o primeiro registro deste comportamento para Exoplectrini.
\end{abstract}

PALAVRAS-CHAVE. Exoplectra miniata; Exoplectrini; Inga edulis; Leguminosae; recurso alimentar.

Coccinellidae is a well-known beetle family, worldwide distributed and divided into six subfamilies: Coccidulinae, Coccinellinae, Scymninae, Chilocorinae, Sticholotidinae and Epilachninae (Vandenberg 2002). Except for the mycophagous Coccinellinae (Halyziini and Tythaspis) and the phytophagous Epilachninae, all remaining coccinellids are predators of hemipteran insects from the suborder Sternorrhyncha (e.g. aphids, scales, psyllids and whiteflies), mites and eventually other insect larvae (Dixon 2000).

Despite their prey of choice, most predatory coccinellids include other non-prey items in their diet (e.g. honeydew, pollen, sap, nectar and various fungi (see Pemberton \& Vandenberg 1993; Lundgren 2009). The exact role of these items play in the natural history of these predators is not well understood. It has been recently argued that these so called "alternative" food sources might play a more important role than it was originally suggested. In the classical view, "alternative" food is utilized to provide sufficient energy to compensate for metabolic losses or to accumulate reserves for dormancy whenever the preferred prey, or "essential" food, is scarce (Hodek 1973; Hodek \& Honk 1996). However, a meta analysis by Lundgren (2009) showed that a supplement of sugar would improve the performance of some predator coccinellids. These results suggest that, at least for some coccinellids, non-prey food sources might be necessary for the optimal predator's performance. A phylogenetic study by Giorgi et al. (2009) further corroborates the importance of a non-prey item (pollen) in the evolution of feeding strategies for predator coccinellids. Entomophagous Coccinellidae are important agents in the biological control of agricultural and forest pests (Obrycki \& Kring 1998). Thus, understanding how these predators utilize these non-prey items might prove useful in improving the performance of these predators in the field. Such studies can also improve our knowledge on the coccinellids behavior repertoire.

According to Sloggett \& Majerus (2000), coccinellids adopt a variety of foraging strategies to acquire resources for their survival when food is scarce, normally unused when their prey is abundant. Analysis of the gut content of Chilocorus kuwanae (Silvestri) (Chilocorini), a natural enemy of euonymus scale, Unaspis euonymi demonstrated the presence of pollen and nectar (Nalepa et al. 1992). For some species, pollen and nectar can represent an essential food.

In this contribution, we provide the first record of an Exoplectrini species feeding on extrafloral nectaries (EFN). In December of 2006, Exoplectra miniata (Germar, 1824) was observed feeding on EFN of Inga edulis Mart. (Figs. 1-4) in a reforestation area, near an urban area in Nova Friburgo, Rio de Janeiro state, Brazil (22॰162 $\left.443 \mathrm{~S}, 42^{\circ} 302333 \mathrm{~W}, 1,060 \mathrm{~m}\right)$. Individuals of $E$. miniata were observed feeding on the nectar of I. edulis for about 10 to 15 minutes. While feeding, E. miniata kept the hind legs over the plant stem and the middle and the fore legs over the border of the nectary. The pronotum was bended downwards and the head completely inserted inside the nectary. 

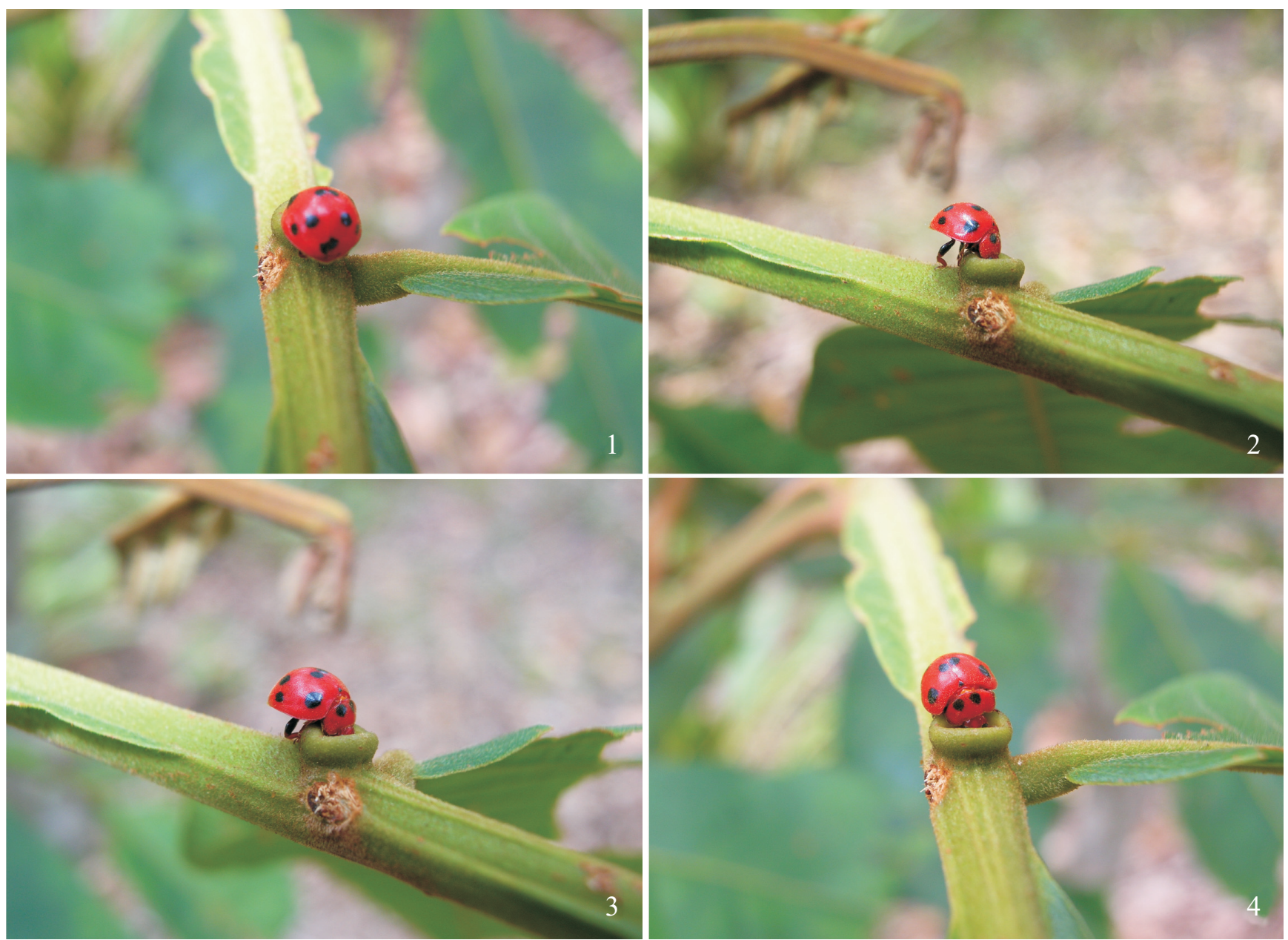

Figs. 1-4. Exoplectra miniata (Germar) feeding on extrafloral nectary of Inga edulis Mart. (Mimosoidae).

Exoplectra Chevrolat comprises 37 species of almost exclusive Neotropical distribution (Gordon 1985; Costa et al. 2008). The Brazilian species of Exoplectra were revised by Costa et al. (2008), which record the distribution of E. miniata for the states of Distrito Federal, Espírito Santo, Minas Gerais, Rio de Janeiro and Paraná. The presence of mandibles with strong apical teeth indicates the predatory habit of the species of this genus (Gordon 1985). However, little is known about their food preferences. Schilder \& Schilder (1928) reported Exoplectra shaefferi, the only representative of the genus occurring in the Neartic region (Gordon 1985), feeding on the whitefly Aleurodicus cocois (Curtis, 1846) (Hemiptera, Aleyrodidae). Bartoszeck (1980) reported larvae and adults of Exoplectra sp. preying on Toxoptera citricidus (Kirkaldy, 1907) (Hemiptera, Aphididae). Drea \& Gordon (1990) reported Exoplectra dubia Crotch, 1874, feeding on Aspidiotus sp. (Hemiptera, Diaspididae).

The use of other non-prey items by species of Exoplectrini has been suggested by Gordon (1985) and Giorgi et al. (2009). Based on observation of supposedly mandible marks on Bamboo trees, Gordon (1985) suggested that E. shaefferi could be feeding on plant material. Giorgi et al. (2009) reported the presence of fungi (unidentified spores and conidia of Convularia sp. and Cercospora sp.) in the gut content of an unidentified Exoplectrini.

Extrafloral nectaries are present in at least 93 plant families and 332 genera around the world (Koptur 1992). The purpose of this structure is to attract entomofagous natural enemies, acting as an indirect defense mechanism against the herbivores (Heil et al. 2001; Kost \& Heil 2006). Nectar is an aqueous solution of mostly sugar, but also includes aminoacids, and other organic compounds (Baker \& Baker 1975, 1983; Baker 1977). At least 15 sugars have been found in EFN (Lundgren 2009), including mono, di and oligo-saccharides, being sucrose and its metabolites the most abundant one (Torres \& Galetto 2002; Petanidou 2005).

Even though coccinellids might eventually feed on flower nectary (FN), Lundgreen (2009) reports that literature research shows that EFN are used more frequently. Nectar from FN is usually not available for the predators since its primary function is to attract pollinators (Bentley 1977). FN architecture as well as the chemical composition of nectar plays an important role in discouraging nectar thievery from flowers (Lundgren 2009). Because these nectaries have 
evolved under distinct selective pressures, floral and extra floral nectars also differ in their nutritional properties (Bentley 1977; Lundgren 2009).

According to Byk \& Del-Claro (2011) ant colonies with access to extrafloral nectar would have higher benefit than colonies without access, because they would have an additional source of energy and amino acids. The authors discuss the significant and positive impact of EFN on ant fitness in terms of colony growth rate, survival and weight of eggs and individuals.

The Neotropical genus Inga Mill. (Legumisosae, Mimosoidae) has about 300 species (Pennington 1997). It is an ecologically important plant, which supplies nectar, pollen, fruits and seeds to the local fauna (Elias 1981; Koptur 1994; Ragusa-Netto \& Fecchio 2006). Its main characteristic is the presence of foliar nectaries between each foliole pair (Possette \& Rodrigues 2010). Inga edulis Mart. extends from Colombia and Venezuela to Argentina. This species occurs in rain forest, at an altitude ranging from 750 to $1,200 \mathrm{~m}$. In Brazil, it occurs in the Atlantic coast, from Ceará state to the northern coastline of the state of Santa Catarina (Pennington 1997). The nectaries of $I$. edulis are sessile, showy and transversely compressed (Figs. 3 and 4) (Possette \& Rodrigues 2010).

Pemberton \& Vandenberg (1993) have provided a detailed review of the use of EFN by Coccinellidae. According to these authors, forty-one species of coccinellids have been reported to feed on extrafloral nectar of 32 species of plants. The coccinellid species belong to 23 genera that are distributed in 8 tribes representing 5 different subfamilies: Scymnini, Stethorini, Brachiacanthini (Scymninae), Chilocorini (Chilocorinae), Coccidulini (Coccidulinae), Coccinellini, Halyziini (Coccinellinae), and Epilachnini (Epilachninae). The plant species belong to 23 genera representing 15 families. We are adding to this list a new record of species and tribe of Coccinellidae, and a new record of plant species. This additional data on the food habit of E. miniata suggests a remarkable diverse diet for the Exoplectrini and future studies can prove that EFN as food can provide nutrients for higher fitness of predators.

\section{ACKNOWLEDGMENTS}

We thank the reviewers for critically reading the manuscript and $\mathrm{CNPq}$ - Conselho Nacional de Desenvolvimento Científico e Tecnológico for the doctoral fellowship GHC (140229/2008-6), PCG (140181/2007-5) and for the research fellowship LMA (306772/2006-0). This is the contribution number 1791 of Department of Zoology, Universidade Federal do Paraná.

\section{REFERENCES}

Baker, H. G. \& I. Baker. 1975. Nectar constitution and pollinator-plant coevolution, p. 100-140. In: L. E. Gilbert \& P. H. Raven (eds.). Animal and plant coevolution. Austin, Texas University Press, 263 p.

Baker, H. G. \& I. Baker.1983. A brief historical review of the chemistry of floral nectar, p. 153-173. In: T. S. Elias \& B. L. Bentley (eds.). The biology of nectarines. New York, Columbia University Press, 259 p.

Baker, H.G. 1977. Non-sugar chemical constituents of nectar. Apidologie 8: 349-356.

Bartoszeck, A. B. 1980. Ocorrência de Toxoptera citricidus (Aphididae) e seus inimigos naturais em Imperatriz, MA, Brasil. Dusenia 12: 8-13.

Bentley, B. L., 1977. Extrafloral nectaries and protection by pugnacious bodyguards. Annual Review of Ecology and Systematics 8: 407-427

Byk, J. \& K. Del-Claro. 2011. Ant-plant interaction in the Neotropical savanna: direct beneficial effects of extrafloral nectar on ant colony fitness. Population Ecology 53: 327-332.

Costa, A. V.; L. M. Almeida, \& G. H. Corrêa. 2008. Revisão das espécies brasileiras do gênero Exoplectra Chevrolat (Coleoptera, Coccinellidae, Exoplectrinae, Exoplectrini). Revista Brasileira de Entomologia 52 : 365-382.

Dixon, A. F. G. 2000. Insect predator-prey dynamics. Ladybirds beetles \& biological control. London, Cambridge University Press, $257 \mathrm{p}$.

Drea, J. J. \& R.D. Gordon. 1990. Predators. 2.2.1. Coccinellidae, p. 19-40. In: D. Rosen (ed.). The armored scale insects, their biology, natural enemies and control. Amsterdam, Elsevier, p. 688

Elias, T. S. 1981. Mimosoideae. p.143-151. In: R.M. Polhil \& P.H. Raven (eds.). Advances in Legume Systematics. Kew, Royal Botanic Gardens, v. 2.

Giorgi, J. A.; N. J. Vandenberg; J. V. McHugh; J. A. Forrester; A. ZlipiDski; K. B. Miller; L. R. Shapiro \& M. F. Whiting. 2009. The evolution of food preferences in Coccinellidae. Biological Control 51: 215-31.

Gordon, R. D. 1985. The Coccinellidae (Coleoptera) of America North of Mexico. Journal of New York Entomological Society 93: 1-912.

Heil, M.; T. Koch; A. Hilpert; B. Fiala; W. Boland \& K.E. Linsenmair. 2001. Extrafloral nectar production of the ant-associated plant, Macaranga tanarius, is an induced, indirect, defensive response elicited by jasmonic acid. Proceedings of the National Academy of Sciences 98: 10831088.

Hodek, I. \& A. Honk. 1996. Ecology of Coccinellidae. Dordrecht, Kluwer Academic Publishers, 464 p.

Hodek, I. 1973. Biology of Coccinellidae. Prague, Academia Publishing House of the Czechoslovak, Academy of Sciences, $260 \mathrm{p}$.

Kost, C. \& M. Heil. 2006. Herbivore-induced plant volatiles induce an indirect defence in neighbouring plants. Journal of Ecology 94: 619-628.

Koptur, S. 1992. Extrafloral nectar-mediated interactions between insects and plants, p. 81-129. In: E. Bernays (ed.). Insect-plant interactions. Boca Raton, CRC Press, 487 p.

Koptur, S. 1994. Floral and extrafloral nectars of Costa Rica Inga trees: A comparison of their constituents and composition. Biotropica 26: 276284.

Lundgren, J. G. 2009. Nutritional aspects of non-prey foods and the life histories of predaceous Coccinellidae. Biological Control 51: 294 305.

Nalepa, C. A.; S. B. Bambara \& A. M. Burroughs. 1992. Pollen and nectar feeding by Chilocorus kuwanae (Silvestri) (Coleoptera: Coccinellidae). Proceedings of Entomological Society of Washington 94: 596-597.

Obrycki, J. J. \& T. J. Kring. 1998. Predaceous Coccinellidae in biological control. Annual Review of Entomology 43: 295-321.

Pemberton, R. W. \& N. J. Vandenberg. 1993. Extrafloral nectar feeding by ladybird beetles (Coleoptera: Coccinellidae). Proceedings of the Entomological Society of Washington 95: 139-151.

Pennington, T. D. 1997. The Genus Inga. Botany. Kew, Royal Botanical Garden, 844 p.

Petanidou, T. 2005. Sugars in Mediterranean floral nectars: an ecological and evolutionary approach. Journal of Chemical Ecology 31: 1065 1088 .

Possette, R. F. S. \& W. A. Rodrigues. 2010. O gênero Inga Mill. (Leguminosae - Mimosoideae) no estado do Paraná, Brasil. Acta Botanica Brasileira 24: 354-368.

Ragusa-Netto, J. \& A. Fecchio. 2006. Plant food resources in diet of a parrot community in a gallery forest of the Southern Pantanal (Brazil). Brazilian Journal of Biology 66: 1021-1032. 
Schilder, F. A. \& M. Schilder. 1928. Die Nahrung der Coccinelliden und ihre Beziehung zur Verwandschaft der Arten. Arbeiten aus der biologischen Reichsanstalt für Land und Forstwirtschaft 16: 213282.

Sloggett, J. J. \& M. Majerus. 2000. Habitat preferences and diet in the predatory Coccinellidae (Coleoptera): an evolutionary perspective. Biological Journal of the Linnaean Society 70: 63-88.
Torres, C. \& L. Galetto. 2002. Are nectar sugar composition and corolla tube length related to the diversity of insects that visit Asteraceae flowers? Plant Biology 4: 360-366.

Vandenberg, N. J. 2002. Coccinellidae Latreille, 1807, p. 371-389. In: R. H. Arnett \& M.C. Thomas, (eds.). American Beetles. Vol.2. Polyphaga: Scarabaeoidea through Curculionoidea. Boca Raton, CRC Press, 861 p.

Received 10/2/2011; accepted 26/7/2011

Editor: Kleber Del Claro

Revista Brasileira de Entomologia 55(3): 447-450, setembro, 2011 